\title{
Effect of Disinfectants on Antibiotics Susceptibility of
}

\section{Pseudomonas aeruginosa}

\author{
Majid H. Al-Jailawi (Corresponding author) \\ Department of Molecular \& Medical Biotechnology, College of Biotechnology, Alnahrain \\ University, Baghdad, Iraq
}

Tel: 964-781-375-9594 E-mail: majed_algelawi@hotmail.com

Rasha S. Ameen

Department of Molecular \& Medical Biotechnology, College of Biotechnology, Alnahrain

University, Baghdad, Iraq

Tel: 964-770-344-0952_E-mail: rashasadik83@yahoo.com

Montaha R. Al-Jeboori

Department of Biomedical, Al-Khawarizmi College of Engineering, Baghdad University, Baghdad, Iraq

Tel: 964-790-196-4191_E-mail: muntaha2005@yahoo.com

Received: May 20, 2013 Accepted: July 20, 2013 Published: July 23, 2013

doi: 10.5296/jab.v1i1.4038 URL: http://dx.doi.org/10.5296/jab.v1i1.4038

\begin{abstract}
Disinfectants are widely used to get rid of microorganisms whether in hospitals, health centers or for normal domestic use. Some suggested that when disinfectants are incorrectly diluted the disinfectant might promote the growth of antibiotic-resistant bacteria, therefore, in this study pathogenic bacterium (Pseudomonas aeruginosa), isolated from patient with urinary tract infection, treated with two locally popular disinfectants (Claradone and Sarttol). Results showed that the bacterial growth was affected by both disinfectants. The lowest concentration of Claradone that inhibit the growth of this bacterium is considered as the minimum inhibitory concentration (MIC), this was $30 \%$, while the lowest effecting concentration of Sarttol was 3\%. A number of survival colonies after treated with high concentration of Calarodone and Sarttol were investigated for their susceptibility to antibiotics, using standard disc diffusion method. Results indicated that these colonies of $P$. aeruginosa resisted antibiotics they were sensitive to before treatment. So it can be concluded that using Claradone and sarttol can make the pathogenic bacterium ( $P$. aeruginosa) resist some antibiotics.
\end{abstract}

Keywords: Pseudomonas aeruginosa, Disinfectants, Minimum Inhibitory Concentration, Claradone, Sarttol 


\section{Introduction}

Pseudomonas aeruginosa is an important opportunistic pathogen (de Bentzmann and Plesiat, 2011). It is one of the main causes of hospital-acquired infections (Machado et al., 2013). Effective antibiotics are limited because infections by $P$. aeruginosa are hard to defy, as it is virulent, acquires antibiotic resistance and resists disinfectants (Higgins et al., 2001; Zavascki et al., 2005). Furthermore, the contaminated disinfectant solutions are the source of nosocomial infections (David \& Moore, 1997; Odjadjare et al., 2012).

Many methods have been contrived to decrease the population and prevalence of causative agents of infectious diseases. They include chemotherapy, immunization, sterilization and disinfection (Kim et al., 2007). Subsequently, decontamination, disinfection and sterilization became main components of any infection control program (Rutala et al., 2001).

Onaolapo (2001) and Aboh et al. (2013) defined antiseptics as biocides or products that destroy or inhibit the growth of microorganisms in or on living tissue (e.g. health care personnel hand washes and surgical scrubs); and disinfectants are also products or biocides that are used on inanimate objects or surfaces.

The formulation of disinfectants, level of organic charge, synergy, temperature, dilution rate and examination methods influence the antimicrobial activity of disinfectants (Russel et al., 1995; Russel, 2002). The mechanisms of action of antiseptics and disinfectants on bacteria include examination of uptake (Russell \& Chopra, 1996), lysis and leakage of intracellular constituents (Christopher et al., 2007), perturbation of cell homeostasis (Kroll and Patchett, 1991), effects on model membranes (Denyer \& Stewart, 1998), inhibition of enzymes, electron transport, and oxidative phosphorylation (Kuyyakanond \& Quesnel, 1992; McDonnell \& Russell, 1999).

Pseudomonas aeruginosa was extensively studied for its high incidence and extraordinary potential to form biofilms in clinical equipment, medical devices and wounds (Hill et al., 2010; de Bentzmann \& Plésiat, 2011). Biofilms represent a reservoir of pathogenic bacteria that can disconnect, proceed their planktonic state, and contaminate new surfaces and patients. Moreover, microbial biofilms are well known for their high level of resistance towards antibiotic and biocide treatments (Gilbert et al., 2001). Bacteria within biofilms can easily live in the presence of high antibiotic concentrations similar to the ones that are prescribed during the course of therapies (Russell, 2003; Dorr et al., 2009). Biofilm resistance mechanisms include not only the reaction-diffusion limitation of antimicrobial access to the biofilm-entrapped bacteria (Gilbert et al., 2003), but also the expression of spatially heterogeneous, less susceptible phenotypes, caused either by growth as a biofilm per se, or through the expression of high cell density, or starvation phenotypes. The use of certain active substances in biocides in various settings may contribute to the increased occurrence of antibiotic resistant bacteria (Machado et al., 2013).

Attention is being directed to the susceptibility of different types of microorganisms to antiseptics and disinfectants. Susceptibility vary in bacteria from one to another, the bacterial spores are the most resistant, followed by mycobacteria, then Gram-negative bacteria, and generally cocci are the most sensitive (Russell, 1999). There is a need to establish linkage between antibiotic and disinfectant resistance in bacteria and whether disinfectants can cause 
antibiotic resistance. Some researchers referred that the effect of disinfectants on microorganisms is concentration-dependent, and due to the importance of disinfectants in the prevention of hospital-acquired infections, this study was carried out to confirm whether using of disinfectants could make bacteria resist some antibiotics.

\section{Materials and Methods}

\subsection{Bacterial Isolate}

The bacterium used in this study is clinical isolate of Pseudomonas aeruginosa, isolated from patient with urinary tract infection and obtained from Department of Biotechnology at Alnahrain University.

\subsection{Disinfectants}

Disinfectants used in this study are common and commercial, Claradone (40\% w/v), which contain povidone iodine and Sarttol $(5 \% \mathrm{w} / \mathrm{v})$, contain dichloro-meta xylen and isopropyl alcohol.

\subsection{Antibiotic Susceptibility Test (Atlas et al., 1995; CLSI, 2006)}

The susceptibility of the isolate to antibiotics was determined by the disc diffusion test. A sterile cotton swab was dipped into the inoculum's of freshly culture (18 hrs. old) and the entire surface of the Muller Hinton agar plates was swabbed three times by rotating the plate approximately $60^{\circ}$ between streaking to ensure even distribution, then the discs of antibiotics were applied and incubated at $37^{\circ} \mathrm{C}$ for $24 \mathrm{hrs}$. The diameter of the inhibition zone (clear area around discs) indicates the sensitivity of bacteria to that antibiotic.

\subsection{Treatment of P. aeruginosa with Disinfectant (Turnidge et al., 2003)}

The response of $P$. aeruginosa to Claradone and Sarttol was detected by the minimum inhibitory concentration (MIC), this bacterium was grown in $10 \mathrm{ml}$ of nutrient broth to mid $\log$ phase. Then $0.1 \mathrm{ml}$ inoculums of the culture were inoculated in a series of $10 \mathrm{ml}$ fresh nutrient broth tubes containing various concentrations of each one of the disinfectant, serial concentration of Claradone are $5 \%, 10 \%, 15 \%, 20 \%, 25 \%$ and $30 \%(\mathrm{w} / \mathrm{v})$, and the serial concentration of Sarttol are $0.1 \%, 0.2 \%, 0.3 \%, 0.4 \%, 0.5 \%, 1 \%, 2 \%$ and $3 \%(\mathrm{w} / \mathrm{v})$. All tubes were incubated at $37^{\circ} \mathrm{C}$ for $24-48 \mathrm{hrs}$.

Bacterial growth was determined by measuring the optical density of the liquid culture in spectrophotometer (Spectronic 20) at $600 \mathrm{~nm}$ and compared with the control (without disinfectant) to determine the effect of disinfectant on bacterial growth. The lowest concentration of disinfectant that inhibited the growth of the bacterium considered as the minimum inhibitory concentration (MIC).

Samples were taken from tubes containing the highest concentration of disinfectant that still allow bacterial growth, and $0.1 \mathrm{ml}$ samples were spread on nutrient agar plates and incubated overnight at $37{ }^{\circ} \mathrm{C}$ to score the survived colonies. Survivors were analyzed for antibiotics resistance as a result of disinfectant effects.

\section{Results and Discussion}

\subsection{Bacterial Treated with Disinfectants}


The bacterium used in this study is clinical isolate of Pseudomonas aeruginosa, which was isolated from patient with urinary tract infection. This isolate was candidate to investigate the effect of disinfectants on its susceptibility to antibiotics, using broth dilution methods.

This bacterium was grown in nutrient broth supplemented with serial dilutions of disinfectant (Claradone and Sarttol). There were two controls, control (1) was a culture broth and control (2) was a culture broth with the disinfectant.

Results presented in Tables 1, 2 show that the bacterial growth was affected by both disinfectants. The lowest concentration of Claradone that inhibited the growth of this bacterium, which is considered as the minimum inhibitory concentration (MIC) was $30 \% \mathrm{w} / \mathrm{v}$, while the lowest concentration of Sarttol was $3 \% \mathrm{w} / \mathrm{v}$.

Table 1. Effect of Claradone on Pseudomonas aeruginosa grown in nutrient broth at $37^{\circ} \mathrm{C}$ for $48 \mathrm{hrs}$

\begin{tabular}{|c|c|c|c|c|c|c|c|c|}
\hline \multirow{2}{*}{ Isolate } & \multicolumn{8}{|c|}{ Serial concentration of Claradone disinfectant } \\
\hline & $30 \%$ & $25 \%$ & $20 \%$ & $15 \%$ & $10 \%$ & $5 \%$ & Control 1 & Control 2 \\
\hline Pseudomonas aeruginosa & -- & \pm & + & ++ & ++ & ++ & +++ & -- \\
\hline
\end{tabular}

Table 2. Effect of Sarttol on Pseudomonas aeruginosa grown in nutrient broth at $37^{\circ} \mathrm{C}$ for 48 hrs

Serial concentration of sarttol disinfectant

Isolate

$$
\begin{array}{lllllllll}
3 \% & 1 \% & 0.5 \% & 0.4 \% & 0.3 \% & 0.2 \% & 0.1 \% & \text { Control } 1 & \text { Control } 2
\end{array}
$$

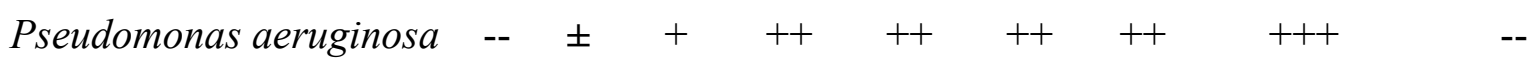

$(+++)$ : Very good growth $(\mathrm{OD} 600=1.25-2.0),(++)$ : Good growth $(\mathrm{OD} 600=0.81-1.2),(+)$ : Moderate growth $(\mathrm{OD} 600=0.51-0.8),( \pm)$ : Slight growth $(\mathrm{OD} 600=0.2-0.5),(-)$ : No growth

It was clear that, when the concentration of Claradone is increased the growth of bacteria decreased. Slightly growth of Pseudomonas aeruginosa was noticed when treated with 25\% of Claradone, while moderate growth and good growth of bacteria was noticed when treated with $20 \%$ and $15 \%, 10 \%$ and $5 \%$ of Claradone respectively (Table 1 ).

In addition, the results depicted in Table 2 show that there was no growth of Pseudomonas aeruginosa when treated with $3 \%$ of Sarttol disinfectant, but the bacterial growth was slight when treated with $1 \%$. Moderate and good growth of bacteria was noticed when treated with $0.5 \%$ and $0.4 \%, 0.3 \%, 0.2 \%$ and 0.1 of Sarttol respectively, compared with bacterial growth 
in control (1) and (2).

Samples were taken from tubes containing the highest concentration of Calarodon $(25 \%)$ and Sarttol (1\%) that still allow bacterial growth, and $0.1 \mathrm{ml}$ samples were spread on nutrient agar plates and incubated overnight at $37{ }^{\circ} \mathrm{C}$ to score the survived colonies. Twenty of survivor colonies for each treatment of Claradone (25\%) and Sarttol (1\%) were selected and checked for their antibiotic susceptibility.

\subsection{Antibiotic susceptibility of Pseudomonas aeruginosa}

\subsubsection{Before Treatment with Disinfectants}

The standard disc diffusion method was used to determine the sensitivity of $P$. aeruginosa isolate to several antibiotics. Table 3 showed that the isolate was resistant to Amikacin, Ampicillin, Azithromycin, Cefotaxime, Cephradine, Chloramphenicol, Novobiocin, Penicillin, Pipracillin, Rifampin, Vancomycin and tetracycline as illustrated in figure 1, and the isolate was sensitive to Cephalothin, Gentamicin, Ciprofloxacin, Nalidixic acid, Cloxacillin, Doxycycline, Streptomycin and Norfloxacillin. The multidruge resistance of bacteria could be due to the permeability of the outer membrane, which might prevent the entry into the cell of most of these antibiotics or due to certain mutations that occur as a result of overuse and misuse of antibiotics, in addition, plasmids and transposons that carrying resistance gene(s) play an important role in spreading the multidruge resistance between bacteria (Aversion et al., 2000; Stock \& Wiedmann, 2001; Robicsek et al., 2006).

Table 3. Antibiotic sensitivity of Pseudomonas aeruginosa isolate before and after treatment with disinfectants

\begin{tabular}{|c|c|c|}
\hline \multirow[b]{2}{*}{ Antibiotic Disk } & \multicolumn{2}{|c|}{ Sensitivity of Pseudomonas aeruginosa } \\
\hline & $\begin{array}{c}\text { before treatment with } \\
\text { disinfectants }\end{array}$ & $\begin{array}{l}\text { After treatment with } \\
\text { disinfectants }\end{array}$ \\
\hline Amikacin AK $(30 \mu g)$ & $\mathrm{R}$ & $\mathrm{R}$ \\
\hline Ampicillin AM $(25 \mu \mathrm{g})$ & $\mathrm{R}$ & $\mathrm{R}$ \\
\hline Azithromycin AZM $(15 \mu \mathrm{g})$ & $\mathrm{R}$ & $\mathrm{R}$ \\
\hline Cefotaxime CTX $(30 \mu \mathrm{g})$ & $\mathrm{R}$ & $\mathrm{R}$ \\
\hline Cephradine CE $(30 \mu \mathrm{g})$ & $\mathrm{R}$ & $\mathrm{R}$ \\
\hline Cephalothin KF $(30 \mu \mathrm{g})$ & $\mathrm{S}$ & $\mathrm{S}$ \\
\hline Chloramphenicol C $(10 \mu \mathrm{g})$ & $\mathrm{R}$ & $\mathrm{R}$ \\
\hline Ciprofloxacin CF (5 $\mu \mathrm{g})$ & S & $\mathrm{S}$ \\
\hline Cloxacillin CLX $(30 \mu \mathrm{g})$ & S & $\mathrm{R}$ \\
\hline Doxycycline DO $(30 \mu \mathrm{g})$ & $\mathrm{S}$ & $\mathrm{R}$ \\
\hline Gentamicin CN $(10 \mu \mathrm{g})$ & $\mathrm{S}$ & $\mathrm{S}$ \\
\hline Nalidixic acid NA $(30 \mu \mathrm{g})$ & S & $\mathrm{R}$ \\
\hline Novobiocin NV (30 $\mu \mathrm{g})$ & $\mathrm{R}$ & $\mathrm{R}$ \\
\hline Norfloxacillin Nor $(10 \mu \mathrm{g})$ & S & $\mathrm{R}$ \\
\hline Penicillin $\mathrm{P}(10 \mu \mathrm{g})$ & $\mathrm{R}$ & $\mathrm{R}$ \\
\hline Pipracillin PC $(100 \mu \mathrm{g})$ & $\mathrm{R}$ & $\mathrm{R}$ \\
\hline Rifampin RA $(5 \mu \mathrm{g})$ & $\mathrm{R}$ & $\mathrm{R}$ \\
\hline
\end{tabular}




$\begin{array}{cll}\text { Streptomycin S }(10 \mu \mathrm{g}) & \mathrm{S} & \mathrm{S} \\ \text { Tetracycline TE }(10 \mu \mathrm{g}) & \mathrm{R} & \mathrm{R} \\ \text { Vancomycin VA }(30 \mu \mathrm{g}) . & \mathrm{R} & \mathrm{R}\end{array}$

R: Resistance; S: Sensitive.

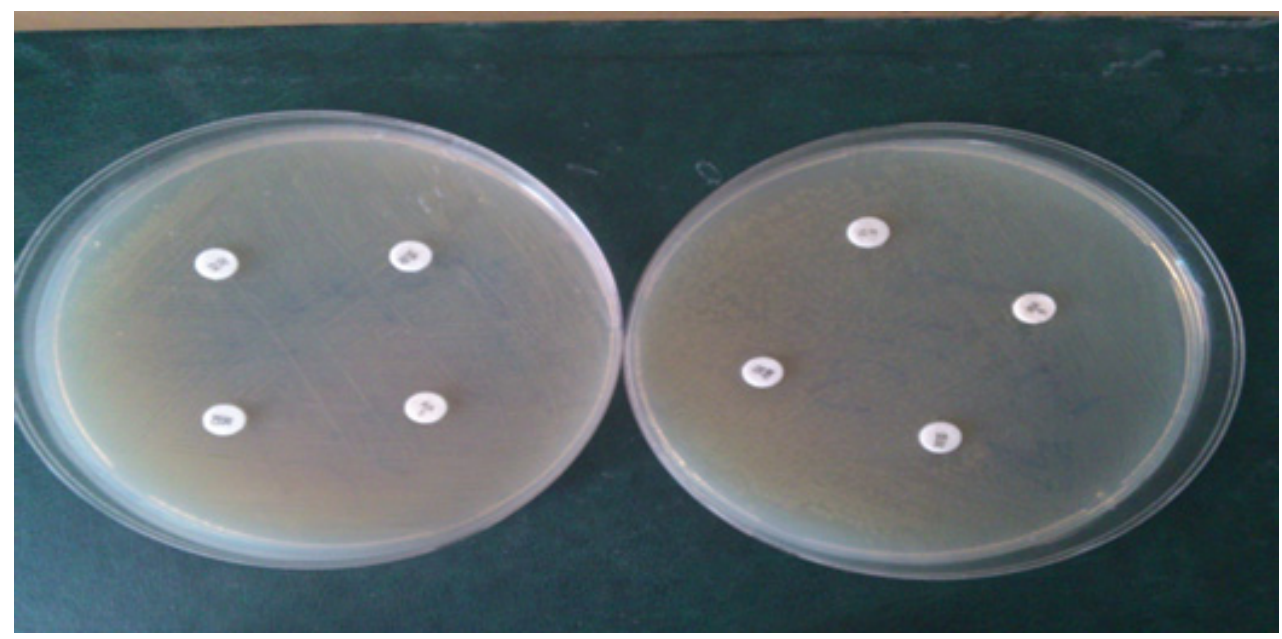

Figure 1. Shows Pseudomonas aeruginosa resistance to some antibiotics

\subsubsection{After Treatment with Disinfectants}

The selected survivor colonies after treated with Claradone and Sarttol were investigated for their susceptibility to antibiotics. It was noticed that some of these colonies (from both treatments) of Pseudomonas aeruginosa became resistant to Nalidixic acid, Norfloxacillin, Cloxacillin and Doxycycline, which was sensitive to them before treatment. As shown in Figures 2, 3. And Table 3.

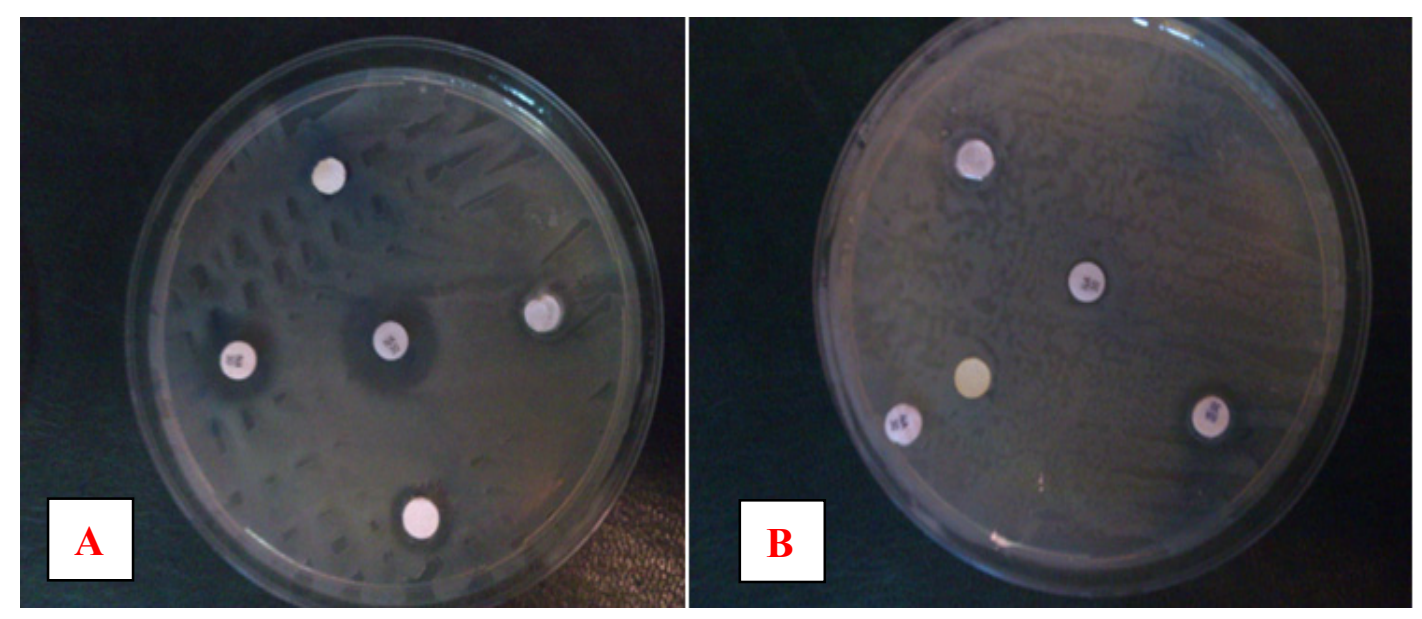

Figure 2. Shows Antibiotics susceptibility of Pseudomonas aeruginosa (A) before treatment to disinfectant, $(\mathrm{B})$ after treatment to disinfectant 


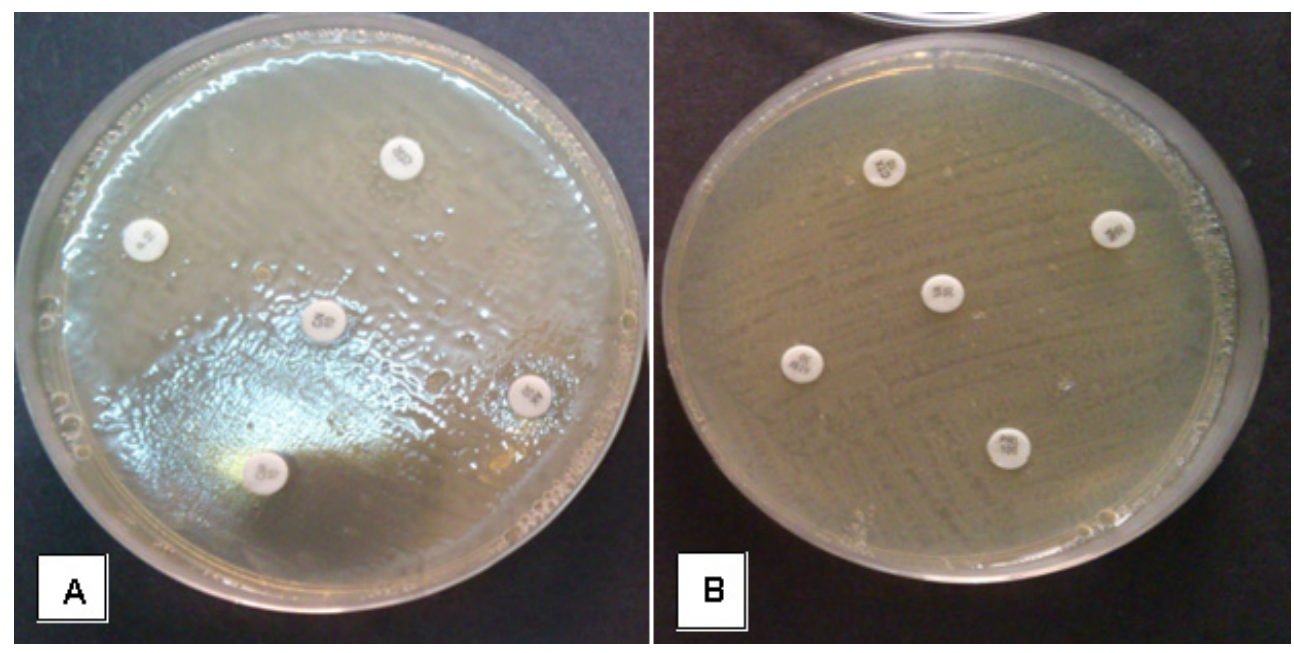

Figure 3. Shows Antibiotics susceptibility of Pseudomonas aeruginosa (A) before treatment to disinfectant, (B) after treatment to disinfectant

These results pointed that treatment of Pseudomonas aeruginosa with sub-MIC of Claradone and Sarttol make this bacterium to become resistant to some antibiotics. These results were consistent with those of Olukemi and Funmilayo (2011), who found that the use of sub-inhibitory concentrations of the disinfectants causes a development in resistance and virulence of bacterial strains. They concluded that using lower concentrations of disinfectants than advised by the manufacturers might have serious influence on bedridden patients.

Poole (2002) reported that the resistance of microorganism to disinfectants typically results from a change in their cells that is affected by disinfectant accumulation, expression of efflux mechanisms and rarely from mutations.

Iroha et al. (2011) elucidated in their study that the continuous usage of disinfectants lead to the evolve of some nosocomial microorganisms and became resistant to antibiotics.

In the study of Mc Cay et al. (2010) they investigated, the theory of adaptation to disinfectants can develop antibiotic resistance. They related it to the type of the antibiotic, mainly the disinfectant and to the organism. Further to this, they concluded that the sub-MIC of disinfectant could keep and choose the coadapted bacteria in the natural environment; the outcome of the selection process is highly affected by disinfectant concentration and the limitation of nutrients.

In this study, the development of $P$. aeruginosa resistance to antibiotics may be a result of adaptation to the disinfectant used. The precise role of plasmids in disinfectant resistance and the biochemical, physiological and molecular changes in the bacteria after using disinfectants are unknown and need extensive studies. To shed more light on the relationship between development of antibiotic resistance and constant using of disinfectant, it is recommended to include more examples of opportunistic bacteria, in future.

\section{Conclusion}

It can be concluded that disinfectants (Claradone and Sarttol) can a train Pseudomonas aeruginosa to resist some antibiotics and become multidrug resistant (superbug), when these disinfectants incorrectly diluted. 


\section{Acknowledgement}

The authors are grateful to Department of Biotechnology College of Science at Alnahrain University, Baghdad, Iraq.

\section{References}

Aboh, M. I., Oladosu, P., \& Ibrahim, K. (2013). Antimicrobial Activities of Some Brands of Household Disinfectants Marketed In Abuja Municipal Area Council, Federal Capital Territory, Nigeria. American Journal of Research Communication, 1-12.

Atlas, R. M., Parks, L. C., \& Brown, A. E. (1995). Laboratory manual of experimental microbiology, mosby-year book, Inc, USA.

Aversion, M. B., Bennett, P. M., \& Walsh, T. R. (2000). Beta-lactamases expression in: P. aeruginosa J. Antimicrobiol. Chemotherapy., 45, 877-880.

Christopher. J. I., Geoff, W. H., \& Stephen, P. D. (2007). Action of Disinfectant Quaternary Ammonium Compounds against Staphylococcus aureus. Antimicrob. Agents Chemother, 51(1), 296-306. http://dx.doi.org/10.1128/AAC.00375-06

CLSI. (2006). Performance Standards for Antimicrobial Susceptibility Testing; Sixteenth Informational Supplement, M100-S16; Clinical and Laboratory Standards Institute: Wayne, PA, USA. 26 (1), 183.

David, M., \& Moore, D. V. M. (1997). Reference Paper: Pseudomonas and the Laboratory Animal. CRL 10(4).

de Bentzmann, S., \& Plesiat, P. (2011). The Pseudomonas aeruginosa opportunistic pathogen and human infections. Environ Microbiol, 13(7), 1655-65. http://dx.doi.org/10.1111/j.1462-2920.2011.02469.x

Denyer, S. P., \& Stewart, G. S. A. B. (1998). Mechanisms of action of disinfectants. International Biodeterioration \& Biodegradation, 41(3-4), 261-268. http://dx.doi.org/10.1016/S0964-8305(98)00023-7

Dorr, T., Lewis, K., \& Vulic, M. (2009). SOS response induces persistence to fluoroquinolones in Escherichia coli. PLoS Genetics, 5(12), e1000760. http://dx.doi.org/10.1371/journal.pgen.1000760

Gilbert, P., Das, J. R., Jones, M. V., \& Allison, D. G. (2001). Assessment of resistance towards biocides following the attachment of microorganisms to, and growth on, surfaces. $J$. Appl Microbiol, 91(2), 248-54. http://dx.doi.org/10.1046/j.1365-2672.2001.01385.x

Gilbert, P., McBain, A. J., \& Rickard, A. H. (2003). Formation of microbial biofilm in hygienic situations: a problem of control. Int Biodeterior Biodegradation, 51(4), 245-48. http://dx.doi.org/10.1016/S0964-8305(03)00043-X

Higgins, C, S., Murtough, S. M., Hiom, S. J., Payne, D. J., Russell, A. D., \& Walsh, T. R. (2001). Resistance to antibiotics and biocides among non-fermenting Gram-negative bacteria. Clin Microbiol Infect Dis., 7, 308-315. http://dx.doi.org/10.1046/j.1198-743x.2001.00253.x 
Hill, K. E., Malic, S., Mckee, R., Rennison, T., Harding, K. G., Williams, D. W., \& Thomas, D. W. (2010). An in vitro model of chronic wound biofilms to test wound dressings and assess antimicrobial susceptibilities. $J$ Antimicrob Chemother, 65(6), 1195-206. http://dx.doi.org/10.1093/jac/dkq105

Iroha, I. R., Oji, A. E., Nwosu, O. K., \& amadi, E. S. (2011). Antimicrobial activity of savlon, izal and 2-germicide against clinical isolate of $P$. aeruginosa from hospital wards. European J. of Dentistry and Midicin, 3(1), 32-35. http://dx.doi.org/10.3923/ejdm.2011.32.35

Kim, Y. M., Farrah, S., \& Baney, R. H. (2007). Structure-antimicrobial activity relationship for silanols, a new class of disinfectants, compared with alcohols and phenols. Int. J. Antimicrob. Ag., 29, 217-222.

Kroll, R. G., \& Patchett, R. A. (1991). Biocide-induced perturbations of cell homeostasis: intracellular pH, membrane potential and solute transport. Soc. Appl. Bacterial. Tech. Ser., 27, 189- 202. http://dx.doi.org/10.1016/j.ijantimicag.2006.08.036

Kuyyakanond, T., \& Quesnel, L. B. (1992). The mechanism of action of chlorhexidine. FEMS microbial. Lett., 100, 211- 216. http://dx.doi.org/10.1111/j.1574-6968.1992.tb05705.x

Machado, I., Graça, J., Lopes, H., Lopes, S., \& Pereira, M. O. (2013) antimicrobial Pressure of ciprofloxacin and Gentamicin on biofilm development by an endoscope-Isolated Pseudomonas aeruginosa. ISRN Biotechnology, 10.

Mc Cay, P. H., Ocampo-Sosa, A. A., \& Fleming, G. T. A. (2010). Effect of subinhibitory concentrations of benzalkonium chloride on the competitiveness of Pseudomonas aeruginosa grown in continuous Culture. Microbiology, 156, 30-38. http://dx.doi.org/10.1099/mic.0.029751-0

McDonnell, G., \& Russell, A. D. (1999). Antiseptics and Disinfectants: Activity, Action, and Resistance. Clin. Microbiol. Rev., 12(1), 147-179.

Odjadjare, E. E., Igbinosa, E. O., Mordi, R., Igere, B., Igeleke, C. L., \& Okoh, A. I. (2012). Prevalence of Multiple Antibiotics Resistant (MAR) Pseudomonas Species in the Final Effluents of Three Municipal Wastewater Treatment Facilities in South Africa. Int. J. Environ. Res. Public Health., 9, 2092-2107. http://dx.doi.org/10.3390/ijerph9062092

Olukemi, O. A., \& Funmilayo, O. A. (2011). The efficacy of the commonly used hospital disinfectants on Pseudomonas aeruginosa. International Research Journal of Microbiology, 2(7), 226-229.

Onaolapo, J. A. (2001). Effects of sub- recommended dilutions of SavlonR on the pathogenicity of P. aeruginosa. J.P.T., 6(2), 116.

Poole, K. (2002). Mechanism of bacterial biocide and antibiotic resistance. J Appl Microbiol Symp 92 (Suppl.), 55S-64S. http://dx.doi.org/10.1046/j.1365-2672.92.5s1.8.x 


\section{Macrothink}

Robicsek, A., Jacoby, G. A., \& Hooper, D. C. (2006). The worldwide emergence of plasmid-mediated quinolone resistance. Lancet. Infect. Dis, 6, 629-640. http://dx.doi.org/10.1016/S1473-3099(06)70599-0

Russel, A. D., \& Russel, N. J. (1995). Biocides: activity, action and resistance. Symp Soc Gen Microbiol., 53, 327-365.

Russell, A. D. (1995). Activity of biocides against mycobacterium. J. Appl. Bacterial, Symp. Suppl., 81, 87-101. http://dx.doi.org/10.1111/j.1365-2672.1996.tb04602.x

Russell, A. D. (1999). Bacterial resistance to disinfectants: present knowledge and future $\begin{array}{lllll}\text { problems. } J . & \text { of } & \text { Hospital } & \text { infection., } & 43,\end{array}$ http://dx.doi.org/10.1016/S0195-6701(99)90066-X

Russell, A. D. (2003). Biocide use and antibiotic resistance: the relevance of laboratory findings to clinical and environmental situations. Lancet Infect Dis, 3(12), 794-803. http://dx.doi.org/10.1016/S1473-3099(03)00833-8

Russell, A. D., \& Chopra, I. (1996). Understanding antibacterial action and resistance (Ellis Horwood, Chichester, England), $2^{\text {nd }}$ ed.

Rutala, W. A., \& Weber, D. J. (2001). Surface disinfection: should we do it? J. Hosp. Infect., 48, 864-868. http://dx.doi.org/10.1016/S0195-6701(01)90017-9

Stock, I., \& Wiedmann, B. (2001). Natural antimicrobial susceptibilities of P. shigelliodes strains. J. Antimicrob. Chemother, 48, 803-811. http://dx.doi.org/10.1093/jac/48.6.803

Turnidge, J. D., Ferraro, M. J., \& Jorgen, J. H. (2003). Susceptibility test methods: General considerations. Manual of Clinical. Microbiol., 8, 219-223.

Zavascki, A. P., Cruz, R. P., \& Goldani, L. Z. (2005). Risk factors for imipenem resistant Pseudomonas aeruginosa; a comparative analysis of two case-control studies in hospitalized patients. J. Hosp. Infect., 59, 96- 101. http://dx.doi.org/10.1016/j.jhin.2004.09.007

\section{Copyright Disclaimer}

Copyright reserved by the author(s).

This article is an open-access article distributed under the terms and conditions of the Creative Commons Attribution license (http://creativecommons.org/licenses/by/3.0/). 